\section{ANTI-INFLAMMATORY AND ORAL TOXICITY ASSESSMENT OF R-38TM: A TRADITIONAL HERBAL SUPPLEMENT FOR ARTHRITIS}

Anis Amirah Mohamada, Fadzilah Adibah Abdul Majida, Suvik Assawb, Fadhilah Zainal Abidinc, Anis Fadhlinad, Sudheer Kumar Alurue, Siti Nurazwa Zainolf, Najat Jabbar Ahmedg

alnstitute of Marine Biotechnology, Universiti Malaysia Terengganu, 21030 Kuala Nerus, Terengganu Darul Iman, Malaysia

bSchool of Fisheries and Food Science, Universiti Malaysia Terengganu, 21030 Kuala Nerus, Terengganu Darul Iman, Malaysia cKulliyyah of Dentistry, International Islamic University Malaysia, Indera Mahkota, 25200 Kuantan, Pahang, Malaysia Institute of Food Security and Sustainable Agriculture, Universiti Malaysia Kelantan, 17600 Jeli, Kelantan, Malaysia eDivision of Animal Biotechnology, Department of Zoology, Sri Venkateswara University, Tirupati-517506, Andhra Pradesh, India

fProliv Life Sciences San Bhd, D-1-15, Residensi Bistaria, Jln Ulu Kelang, Taman Ukay Bistari, 68000 Ampang, Selangor Darul Ehsan, Malaysia

gErbil Technical Health College, Erbil Polytechnic University, Erbil, Iraq
Article history

Received

19 April 2021

Received in revised form

28 October 2021

Accepted

7 November 2021

Published Online

20 December 2021

*Corresponding author f.adibah@umt.edu.my

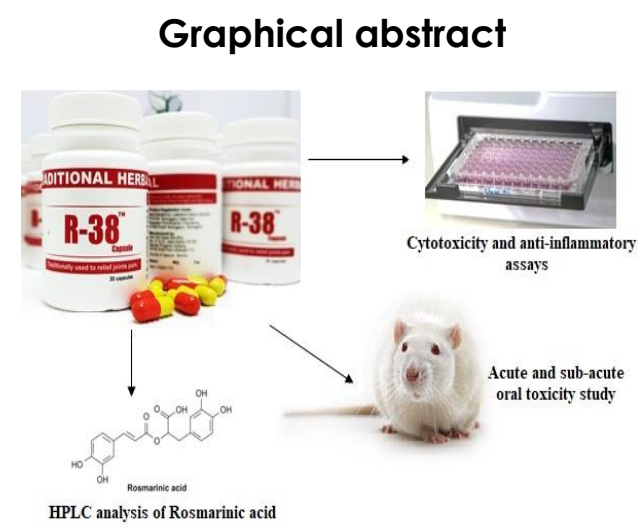

\begin{abstract}
R-38 ${ }^{\text {TM }}$ is a traditional herbal supplement for treating arthritis-related conditions. High-performance liquid chromatography (HPLC) analysis was performed for identification and quantification of rosmarinic acid in the R-38 $8^{\mathrm{TM}}$ water extract. The anti-arthritic potential of the R-38 ${ }^{\mathrm{MM}}$ water extract was investigated by measuring the production of IL-6 and TNF-a in inflamed cells. Xanthine oxidase (XO) and cyclooxygenase-2 (COX-2) inhibition assays were also conducted. The cytotoxic effect of R-38TM water extract was investigated on HSF1 184 cell line. Acute and subacute oral toxicity studies were conducted on female SpragueDawley (SD) rats. The rosmarinic acid was identified at $1.208 \mathrm{~min}(3.61 \% \mathrm{w} / \mathrm{w})$. The inflamed cells showed a decrease in the production of IL-6 (55.9\%) and TNFa (52.13\%). The COX-2 and XO enzymes were moderately inhibited by R-38TM water extract. The cytotoxicity analysis showed no cytotoxic effect on the cell. The acute and subacute oral toxicity studies revealed no mortality and normal body weight at all doses. There were no significant differences $(p>0.05)$ in organ weight, hematological and biochemical parameters, and histology of liver and kidneys with the control group. In conclusion, R-38'M water extract exhibited no toxic effect orally and may possess potential therapeutic properties against pro-inflammatory diseases including arthritis.
\end{abstract}

Keywords: Botanical medicine, R-38TM, anti-inflammatory, oral toxicity, rosmarinic acid, arthritis 


\begin{abstract}
Abstrak
R-38TM adalah suplemen herba tradisional untuk merawat keadaan yang berkaitan dengan arthritis. Analisis Kromatografi Cecair Berprestasi Tinggi (HPLC) telah dilakukan untuk pengenalpastian dan kuantifikasi asid rosmarinik di dalam ekstrak air R-38 ${ }^{\mathrm{TM}}$. Potensi anti-arthritic ekstrak air disiasat dengan mengukur penghasilan IL-6 dan TNF-a dalam sel-sel yang meradang. Asai perencatan xanthine oxidase (XO) dan cyclooxygenase-2 (COX-2) juga dilakukan. Kesan sitotoksik ekstrak air R-38 ${ }^{\mathrm{TM}}$ disiasat pada garis sel HSF1 184. Kajian ketoksikan oral akut dan subakut dilakukan pada tikus Sprague-Dawley (SD) betina. Asid rosmarinik dikenal pasti pada 1.208 minit $(3.61 \% \mathrm{w} / \mathrm{W})$. Sel-sel yang meradang menunjukkan penurunan dalam penghasilan IL-6 (55.9\%) dan TNF-a (52.13\%). Enzim COX-2 dan XO direncat secara sederhana oleh ekstrak air R-38 $\mathrm{TM}$. Analisis sitotoksik menunjukkan tiada kesan sitotoksik kepada sel. Kajian ketoksikan ora akut dan subakut menunjukkan tiada kematian dan berat badan normal pada semua dos. Tiada perbezaan yang signifikan $(p>0,05)$ pada berat organ, parameter hematologi dan biokimia, dan histologi hati dan ginjal dengan kumpulan kawalan. Kesimpulannya, ekstrak air R-38TM tidak menunjukkan kesan toksik secara oral dan mungkin mempunyai sifat terapeutik yang berpotensi terhadap penyakit pro-radang termasuk artritis.

Kata kunci: Ubat botani, R-38'M, anti-radang, ketoksikan oral, asid rosmarinik artritis

(c) 2022 Penerbit UTM Press. All rights reserved
\end{abstract}

\subsection{INTRODUCTION}

Rheumatoid arthritis (RA) is the most prevalent form of inflammatory arthritis. It is a disease of unknown etiology that has affected approximately $1 \%$ of the population worldwide and is correlated with work disability among adults of all ages. The systemic nature of RA involves inflammation of many joints, mainly the lining of synovial joints [1]. In RA symptomatic treatment, non-steroidal antiinflammatory drugs (NSAIDs) are the most prescribed drugs. However, there are limitations and risks associated with the use of these drugs. Hence, the use of alternative therapies involving medicinal herbs is markedly increasing. A previous report stated that more than half of arthritis patients are using complementary and alternative medicine (CAM) [2]. Most of the developing countries $180 \%$ of the population) are still sought for traditional herbal medicines in treating their illnesses as estimated by World Health Organization (WHO) [3].

Traditional herbal medicine has been practiced since ancient times and the growing interest among people towards herbal medicine stipulates the need for thorough investigations into the safety and efficacy of traditional medicines. Though most of these formulations are commonly used by traditional medicine practitioners, yet they still lack scientific evidence. One such Malay traditional herbal medicine, R-38 ${ }^{\mathrm{TM}}$ formulation, is used for its antiinflammatory property, managing arthritic conditions, and improving health with a recommended dose of $300 \mathrm{mg}$ per capsule, once to twice a day. The R-38 ${ }^{\mathrm{TM}}$ comprises of galangal (Alpinia galanga), temulawak (Curcuma xantorrhiza), cat's whiskers (Orthosiphon stamineus), white turmeric (Curcuma zedoaria), and prickly-leaved elephant's foot (Elephantopus scaber L.). The R-38 ${ }^{\mathrm{TM}}$ has been approved by the National Pharmaceutical Regulatory Agency (NPRA), Ministry of Health Malaysia, as traditional medicine (MAL 1703501 1TC) used to relieve joints pain.

The herbal ingredients of R-38 ${ }^{\mathrm{TM}}$ are locally available in Malaysia and well known among traditional medicine practitioners as remedies for arthritis-related conditions $[4,5,6]$. They have been reported to possess bioactivities such as antiinflammatory [4, 7-14], hepatoprotective [15], and anti-arthritic $[7,11,14,16-19]$. They were also reported to have no toxicity effects and considered as safe $[9,10,19-22]$.

One of the ingredients of R-38 $8^{\mathrm{TM}}$ is $\mathrm{O}$. stamineus. It has been reported to contain rosmarinic acid, which is a derivative of caffeic acid [23]. Scientific studies have reported on the anti-inflammatory potential of rosmarinic acid in managing inflammatory diseases. The in vivo treatment with $50 \%$ ethanol leaves extract of $O$. stamineus was reported to exhibit dosedependent inhibitory effects on the rat hind paw edema by significantly decreased synovial hyperplasia, inflammation, and cartilage erosion. It also showed potent inhibition to pro-inflammatory mediators such as Interleukin-1 $\beta$ (IL-1 $\beta$ ), tumor necrosis alpha (TNF-a), cyclooxygenase-1 (COX-1), and COX-2 in vitro [16]. Recently, isolated rosmarinic acid from pomegranate peel was reported to significantly reduce arthritis index score, paw volume, and production levels of TNF-a in Freund's complete adjuvant (FCA)-induced arthritis rats [18].

R-38 ${ }^{\mathrm{TM}}$ presently has no sufficient evidence-based data to support its anti-inflammatory activities, safety, and effectiveness of the formulation. The present study aimed to evaluate the therapeutic potential of 
R-38 ${ }^{\mathrm{TM}}$ water extract by evaluating its antiinflammatory activities and toxicity effects by in vitro and in vivo studies. The rosmarinic acid in the R-38 ${ }^{\mathrm{TM}}$ water extract was also identified and quantified by HPLC analysis.

\subsection{METHODOLOGY}

\subsection{Chemicals and Reagents}

Chemicals used for HPLC analysis such as acetonitrile (HPLC grade), methanol (HPLC grade), and ethanol 95\% (AR grade) were purchased from Sigma-Aldrich (St. Lovis, MO). The standard active compound, rosmarinic acid (SC-202796A) was purchased from Santa Cruz Biotechnology (Dallas, TX). For cytotoxicity study, bacterial lipopolysaccharide (LPS, serotype: 0111:B4, L5293), dispase, collagenase (Type 1), glutamine, penicillin, dissection balanced salt solution (DBBS), fetal bovine serum (FBS), and Dulbecco's Modified Eagle Medium: Nutrient Mixture F-12 (DMEM/F12) were purchased from Gibco (Thermo Fisher Scientific, Waltham, MA). Human Tumour Necrosis Alpha (TNF-a) enzyme-linked immunosorbent assay (ELISA) kit (Catalogue No: RAB0307) and Human Interleukin-6 (IL-6) ELISA kit (Catalogue No: RAB0476) were purchased from Sigma-Aldrich (St. Louis, MO). For the animal study, $10 \%$ neutral buffered formalin solution, $0.9 \%$ normal saline, tolvene (AR grade), xylene (AR grade), absolute ethanol, paraffin wax, Haematoxylin and Eosin (H\&E) solution were procured from Tricell Bioscience Resources, (Selangor, Malaysia). Anaesthetic, KTX (Ketamine-Xylazine/Zoletil) mixture was obtained from the Laboratory Animal Resource Unit (LARU) at Universiti Kebangsaan Malaysia (Selangor, Malaysia).

\subsection{Plant Materials and Extraction}

The coarsely ground of R-38 ${ }^{\mathrm{TM}}$ raw material was purchased from Naturemedics Laboratories Sdn. Bhd. (Kuala Terengganu, Malaysia). The formulation was kept in an air-tight container and stored at $4{ }^{\circ} \mathrm{C}$ until further used. The formulation was soaked in filtered water $(1: 10)$ at $55^{\circ} \mathrm{C}$ and stirred gently for $3 \mathrm{~h}$. The extract was filtered and left to dry completely in the freeze-dryer (Labconco Freezone 4.5 Freeze Dryer, Labconco Corporation, Kansas City, MO) for 7 days. The freeze-dried extract was stored at $4{ }^{\circ} \mathrm{C}$ in an airtight container until further used.

\subsection{Cell Culture}

Human skin fibroblast (HSF1184) cell line (SigmaAldrich) sample was rinsed in Dulbecco's Modified Eagle Medium: Nutrient Mixture F-12 (DMEM/F12) with $2.4 \mathrm{U} / \mathrm{mL}$ dispase, followed by overnight incubation (4 ${ }^{\circ} \mathrm{C}$ ) for facilitating the separation of the epidermis from the dermis. The separated dermal part was washed in dissection balanced salt solution (DBSS), minced, and placed into $0.3 \%$ collagenase (3-4 h) until fully digested at $37^{\circ} \mathrm{C}$. The HSFl 184 was washed with DBSS and cultured in DMEM/F12 supplemented with $10 \%$ FBS. The cells were seeded at $1 \times 10^{4}$ cells $/ \mathrm{cm}^{2}$ in a humidified atmosphere of $5 \% \mathrm{CO}_{2}$ at 37 ${ }^{\circ} \mathrm{C}$.

\subsection{Cytotoxicity Assay on HSF1184 Cell Line}

MTT (3-14, 5-dimethylthiazolyl)-2-yl-2,5diphenyltetrazolium bromide) assay was carried out to determine the $50 \%$ inhibitory concentration $\left(\mathrm{IC}_{50}\right)$ of water extract of R-38 ${ }^{\mathrm{TM}}$ on HSF1 184 cell. The cell viability was tested with the trypan blue exclusion method using Neubaver Improved bright-line hemocytometer (FORTUNA®, Germany). The assay was done following the method by Patel et al. (2009) [24] with modification. Preparation of the sample stock solution was done by dissolving $55 \mathrm{mg}$ of the sample in $550 \mu \mathrm{L}$ of the medium. The MTT assay was carried out with seven different concentrations of $\mathrm{R}$ $38^{\mathrm{TM}}$ water extract from $10^{-1}-10^{5} \mathrm{\mu g} / \mathrm{mL}$ along with control in triplicates. The cells were seeded at $1 \times 10^{4}$ cells $/ \mathrm{mL}$ in a 96-well plate. MTT solution (100 $\mu$ l) was added into wells and incubated for $4 \mathrm{~h}$ at $37^{\circ} \mathrm{C}$. The MTT solution was then discarded and $100 \mu \mathrm{L}$ of MTT solvent (0.1 N HCL-Isopropanol solution) was added into all wells. The number of formazan crystals was recorded using microplate reader Bio-Tek, Model ELX 808 (Bio-Tek, Winooski, VT) at $570 \mathrm{~nm}$ and a reference wavelength of $630 \mathrm{~nm}$. Based on the test finding, concentrations were selected to be used in the antiinflammatory studies of the R-38 ${ }^{\mathrm{TM}}$ water extract on HSF1 184 cell-induced with lipopolysaccharide (LPS).

\subsection{Quantification of Anti-inflammatory Activities}

The anti-inflammatory activity of the R-38 ${ }^{\mathrm{TM}}$ water extract was investigated on lipopolysaccharide (LPS) induced-HSF1 184 cells through the production of IL-6 and TNF-a. Cellular viability was measured using MTT assay while TNF-a and IL-6 production were measured using Human TNF-a ELISA kit and Human IL6 ELISA kit, respectively. The HSFl184 cells were seeded $\left(1 \times 10^{4}\right.$ cells $\left./ \mathrm{mL}\right)$ on three plates of 96-well plates for MTT assay, IL-6, and TNF-a ELISA tests. Four series of each plate were grouped as a positive control, negative control (cells induced with 1.5 $\mathrm{\mu L} / \mathrm{mL} \mathrm{LPS}$ ), treatment I (LPS-induced cells and treated with $10^{4} \mu \mathrm{g} / \mathrm{mL}$ water extract), and treatment II (LPS-induced cells and treated with $10^{5} \mu \mathrm{g} / \mathrm{mL}$ water extract).

Cell viability assay was carried out following the method from Zdarilová et al. (2009) [25] with modification. The cells were induced with LPS for $4 \mathrm{~h}$. The LPS-induced cells were treated with R-38 ${ }^{\text {TM }}$ water extract for $24 \mathrm{~h}$ in 96-well plates. Then, the cells were washed with PBS twice and $20 \mu \mathrm{L}$ of MTT solution (5 $\mathrm{mg} / 1 \mathrm{~mL}$ PBS) was added to each well. The plate was enclosed with aluminum foil and further incubated for $3.5 \mathrm{~h}$. The MTT solution was discarded 
from wells and $200 \mu \mathrm{L}$ of non-sterile DMSO were added to dissolve the formazan produced in the cells. The plate reader (Model ELX 808, Bio-Tek, Winooski, VT) was used to measure the optical density of color formations of each sample at $570 \mathrm{~nm}$ and a reference wavelength at $630 \mathrm{~nm}$. The LPSinduced cells, cultured separately in other 96-well plates, were used to measure IL-6 cytokines and TNFa using commercially available Human ELISA kits based on the manufacturer's protocol. The intensity of the color was measured at $450 \mathrm{~nm}$.

\subsection{Quantification of Xanthine Oxidase and Cyclooxygenase-2 Inhibitory Activities}

The xanthine oxidase (XO) inhibitory bioassay procedure was based on Li et al. (2011) [26]. The assay mixture was prepared by mixing $50 \mu \mathrm{L}$ of test solution (samples or solvents), $35 \mu \mathrm{L}$ of phosphate buffer $(70 \mathrm{mM}, \mathrm{pH}=7.5)$, and $30 \mu \mathrm{L}$ of $\mathrm{XO}$ solution (0.01 $\mathrm{U} / \mathrm{mL}$ in phosphate buffer). The assay mixture was incubated at $25^{\circ} \mathrm{C}$ for $15 \mathrm{~min}$. About $60 \mu \mathrm{L}$ of xanthine solution (150 $\mathrm{MM}$ / in the same buffer) was added into the assay mixture to initiate the reaction and further incubated for $30 \mathrm{~min}$ at $25{ }^{\circ} \mathrm{C}$. The reaction was stopped by adding $25 \mu \mathrm{L}$ of $1 \mathrm{~N}$ hydrochloric acid. All assay was measured by spectrophotometer at a wavelength of $290 \mathrm{~nm}$. Allopurinol was used as the positive control. Sample blank and negative control were prepared similarly, but the enzyme solution was added into the assay mixture after the addition of $1 \mathrm{~N}$ hydrochloric acid. The crude extracts were initially dissolved in DMSO, followed by serial dilutions with the buffer. The final concentration of DMSO for each extract was $0.5 \%$ $\mathrm{v} / \mathrm{v}$.

The cyclooxygenase-2 (COX-2) inhibitory bioassay method was conducted according to the COX-2 screening kit (BioVision K547-100, Milpitas, CA). A 100 $\mu \mathrm{L}$ of unknown concentration of celecoxib was provided in the kit as a positive control. The crude extracts were initially dissolved in DMSO, followed by serial dilutions with the COX assay buffer. The final concentration of DMSO for each test extract was $10 \% \mathrm{v} / \mathrm{v}$. The prepared extracts were pipetted into each well followed by the addition of the master mixture. Lastly, $10 \mu \mathrm{L}$ of arachidonic acid was added into each well and the reaction was initiated. A fluorescence microplate reader (Promega GloMax Multi Detection System, Wisconsin, WI) was used to read the plate with an emission wavelength of 587 $\mathrm{nm}$ and an excitation wavelength of $535 \mathrm{~nm}$. The $96-$ well plate was measured kinetically at $25^{\circ} \mathrm{C}$ for $5-10$ min.

\subsection{Experimental Animals}

All experimental protocols were approved by the Ethics Committee and Research Management and Innovation Centre (Ref. No.: UMT/JKEPT/2018/20) of Universiti Malaysia Terengganu (UMT). The female Sprague-Dawley (SD) rats (5-7 weeks old, 180-200 g) were acclimatized for 7 days before experimentation under standard laboratory conditions $\left(24{ }^{\circ} \mathrm{C} \pm 3^{\circ} \mathrm{C}\right.$ and $12 \mathrm{~h}$ light and dark cycle) with pellet feed and filtered water ad libitum.

\subsection{Acute Oral Toxicity Study}

The study was done according to the Fixed-dose procedure (FDP) from the Organization for Economic Co-operation and Development (OECD) 420 guideline [27]. Fifteen female SD rats were randomly assigned into the control group, treatment I, and treatment II groups. The R-38'M water extract was dissolved in $2 \mathrm{~mL}$ of distilled water and administered to rats by gavage single oral dose of $300 \mathrm{mg} / \mathrm{kg}$ body weight (bw) (treatment I) and $2000 \mathrm{mg} / \mathrm{kg}$ bw (treatment II) while the control group received only distilled water in the same volume. The general observations and mortality were observed daily for 14 days. At the end of the experiment, all rats were fasted overnight, weighed, anesthetized for sample blood collection, and sacrificed for necropsy.

\subsection{Subacute Oral Toxicity Study}

The study was conducted following the 28-day repeated dose from the OECD 407 (2008) guidelines [28]. A total of 30 female SD rats were divided into four groups of 5 female rats (control group, treatment $\mathrm{I}$, treatment II, and treatment III). Additional rats ( $\mathrm{n}=$ 5) were added to the control and treatment III groups as satellite groups for the recovery period. The $\mathrm{R}-38^{\mathrm{TM}}$ water extract was dissolved in $2 \mathrm{~mL}$ of distilled water and administered to rats in treatment groups at a daily oral dose of $300 \mathrm{mg} / \mathrm{kg} \mathrm{bw}$ (treatment I), $1000 \mathrm{mg} / \mathrm{kg}$ bw (treatment II) and $2000 \mathrm{mg} / \mathrm{kg}$ bw (treatment III), while the control group received distilled water in the same volume for 28 days. The animals were fed orally, preferably, at the same time daily. The dose of $2000 \mathrm{mg} / \mathrm{kg}$ bw per day was selected as the maximum dose based on the acute toxicity investigation where the dose was well tolerated with no toxicity events or mortality. All rats were observed daily for general observations, clinical signs, and mortality until the end of the experiment. The satellite groups were kept for another 14 days in the recovery period to observe delayed occurrence of or recovery from toxic effects. At the end of the experiment, all rats were fasted overnight, weighed, anesthetized for blood samples collection, and sacrificed for necropsy.

\subsection{Body and Organ Weight Analysis}

The body weight of all animals in the acute oral toxicity study was measured on day 0 and day 15 (day of necropsy). Whereas the body weights of all animals in the subacute oral toxicity study were recorded once a week during the experiment and recovery period until the day of necropsy. During the scheduled necropsy, all animals were sacrificed, and the liver and kidneys of each rat were isolated, 
washed with $0.9 \%$ normal saline, weighed, and fixed in $10 \%$ neutral buffered formalin for histopathological examination. The absolute organ weights were measured using electrical weighing balance and relative organ weights (organ-to-body weight ratio) were calculated from the rat's body weight on the day of necropsy.

\subsection{Haematological and Biochemical Analysis}

At the end of the experiment, all animals were anesthetized with a KTX mixture. The blood samples were collected via cardiac puncture. All blood samples were analyzed for hematological and biochemical analysis.

\subsection{Histopathological Examination}

The extracted liver and kidneys were washed with $0.9 \%$ normal saline and fixed in a $10 \%$ neutral buffered formalin solution on the day of scheduled necropsy. Briefly, the fixed liver and kidneys were sliced and placed in cassette holders and dehydrated in 50\% ethanol, $70 \%$ ethanol, $95 \%$ ethanol, $100 \%$ ethanol and $100 \%$ tolvene (overnight) gradually. The dried tissues were embedded in paraffin wax and sectioned at approximately 5-6 $\mu \mathrm{m}$ on a microtome. The tissue sections were prepared on glass slides and dried overnight before staining. The slides were stained with haematoxylin and eosin (H\&E) dye solution. The slides were then affixed to the coverslip using DPX mountant. Slides of liver and kidney were examined under a light microscope (Leica DM2500, Wetzlar, Germany) for microscopic examination.

\subsection{HPLC analysis of Rosmarinic Acid}

High-performance liquid chromatography (HPLC) was performed for the quantification of rosmarinic acid in the R-38 ${ }^{\mathrm{TM}}$ water extract. The standard rosmarinic acid was used as a calibration standard. Approximately $2.0 \mathrm{mg}$ of $\mathrm{R}-38^{\mathrm{T}} \mathrm{M}$ water extract was dissolved in $1 \mathrm{~mL}$ of $50 \%$ methanol ( $\mathrm{v} / \mathrm{v}$; methanol in water) and vortexed for $5 \mathrm{~min}$. The standard stock solution of rosmarinic acid was prepared by dissolving $2.0 \mathrm{mg}$ in $1 \mathrm{~mL}$ of $50 \%$ methanol and vortexed for 5 min [29]. Five working standard solutions with a concentration of $20,50,100,200$, and 500 parts per million (ppm) were prepared from the stock solution. The instrument was calibrated and qualified before the analysis. The HPLC analysis was conducted using a Shimadzu Prominence system (Shimadzu Corporation, Japan) with an Agilent Zorbax Eclipse XDG-C 18 column $(4.6$ x 150 mm, $5 \mu \mathrm{m}$ pore size). The system control and data analysis were performed using Shimadzu laboratory solution system software. A mobile phase of acetonitrile (12\%) and ionized distilled water (88 \%) was used for the analysis at $340 \mathrm{~nm}$. The flow rate was $1 \mathrm{~mL} / \mathrm{min}$ and maintained at $35{ }^{\circ} \mathrm{C}$. The total sample injection volume was $20 \mu \mathrm{L}$ and the total run time was $8 \mathrm{~min}$. A calibration curve of the standard was plotted for concentrations in the range of $20-500$ ppm against the peak area.

\subsection{Statistical Analysis}

All data were expressed as mean and standard deviation (mean \pm SD). The homogeneity of variance test was conducted on all values. The comparison between treatment and control groups was performed by one-way analysis of variance (ANOVA) and the significant differences between individual groups were compared using post hoc Tukey's test with IBM SPSS Statistics 22 (IBM, Armonk, NY). The graphs were constructed using GraphPad Prism 5.0 (GraphPad Prism, San Diego, CA). The statistical level of significance was set at a $p<0.05$.

\subsection{RESULTS AND DISCUSSION}

The treatment approach for gout, arthritis and other inflammatory-related diseases always involves the prescription of anti-inflammatory agents to alleviate the symptoms [30]. The ingredients of R-38TM are scientifically known to possess anti-inflammatory properties and have been mostly used in the treatment of arthritic conditions as well as a supplement for general health. The rosmarinic acid in the $O$. stamineus possessed anti-inflammatory activity and was responsible for managing arthritis-related conditions. Anti-inflammatory compounds are commonly detected in the HPLC analysis within the range of 200 to $350 \mathrm{~nm}$ [31]. In the HPLC analysis of R$38^{\mathrm{TM}}$ water extract, rosmarinic acid was identified at $1.15 \mathrm{~min}$, at the wavelength of $340 \mathrm{~nm}$ (Figure 1). The retention time of rosmarinic acid in the water extract of R-38 TM was comparable to the standard compound. The calibration plot was linear over the evaluated concentration range with the correlation coefficient (R2) of rosmarinic acid compound was 0.9998 . The concentration of rosmarinic acid in water extract of R-38 ${ }^{\mathrm{TM}}$ from three replicates injections was $60.94 \pm 0.43 \mu \mathrm{g} / \mathrm{mL}$ or $3.61 \% \mathrm{w} / \mathrm{w}$. 


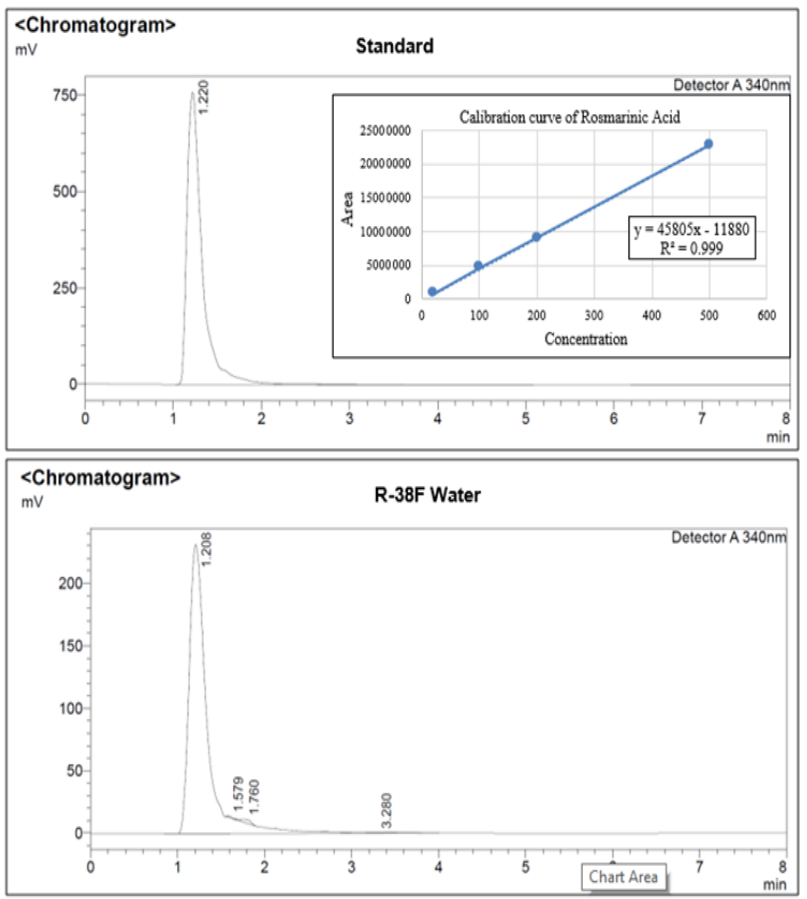

Figure $1 \mathrm{HPLC}$ analysis of rosmarinic acid for standard and R$38^{\mathrm{TM}}$ water extract at $340 \mathrm{~nm}$. The calibration plot of rosmarinic acid shows linear relationship with the correlation coefficient $\left(R^{2}\right)$ of 0.9998

The activity of anti-inflammatory involved suppressing the pro-inflammatory cytokines such as TNF-a, IL-6, and IL-1 $\beta$ [32]. In this study, the antiinflammatory activity of R-38 ${ }^{\mathrm{TM}}$ water extract was evaluated from its inhibitory effect on the production of IL-6 and TNF-a. Lipopolysaccharide (LPS), an irritating agent isolated from the outer membrane of bacteria [25], was used to induce the inflammatory signals in the HSF1184 cell lines. The inflammatory effect from LPS-stimulated macrophages is a reliable marker of inflammation [31]. MTT assay was performed to determine the cytotoxic effect in normal fibroblast cells (HSF1 184) against R-38TM water extract. As shown in Figure 2, the water extract of R$38^{\mathrm{TM}}$ exhibited no cytotoxic effect on the HSFI184 cells. Instead, the normal fibroblast cells have proliferated and showed no inhibitory effect at higher concentrations of $10^{4}$ and $10^{5} \mu \mathrm{g} / \mathrm{mL}$. There was also a significant increase $(p<0.05)$ in the cell proliferation at $10^{5} \mathrm{\mu g} / \mathrm{mL}$ as compared to the control. The two highest concentrations of R-38 ${ }^{\mathrm{TM}}$ water extract were then used in the antiinflammatory activities. The R-38 ${ }^{\mathrm{TM}}$ water extract significantly decreased $(p<0.05)$ the production of the IL-6 and TNF-a in the LPS-induced fibroblast cells in a dose-dependent manner (Figure 3). The production of IL-6 and TNF-a in the LPS-induced HSFl 184 were suppressed by the R-38'M water extract suggesting a potential anti-inflammatory effect. As shown in Figure 4, the R-38 ${ }^{\mathrm{TM}}$ water extract at $10^{5}$ $\mu \mathrm{g} / \mathrm{mL}$ has significantly increased $(p<0.05)$ the survival rate of inflamed fibroblast cells as compared to the normal fibroblast cells. Therefore, the study suggested that the water extract promotes cell growth and increases the LPS-induced HSF1 184 cells survival rate by more than $50 \%$.

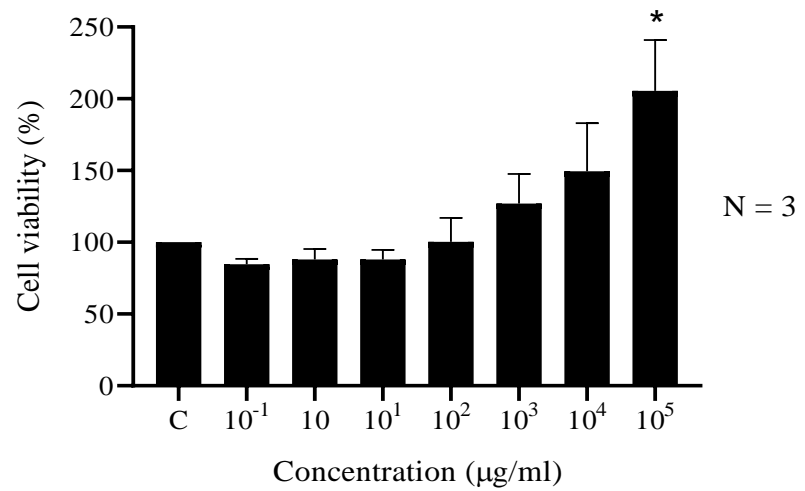

Figure 2 The effects of R-38 ${ }^{\mathrm{TM}}$ water extract on cell viability of normal HSF1 184 cell line using MTT assay. ${ }^{*} p<0.05$ vs control group

(A)

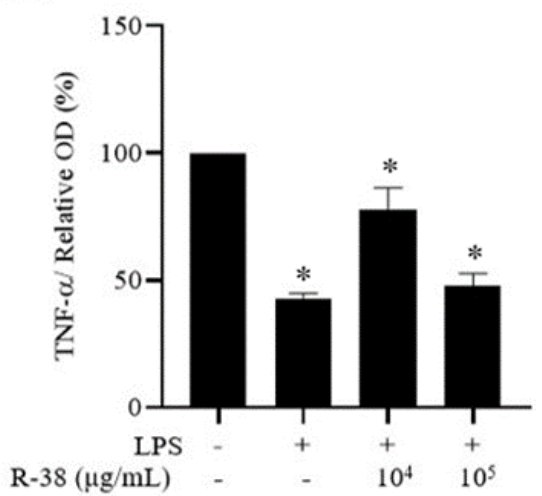

(B)

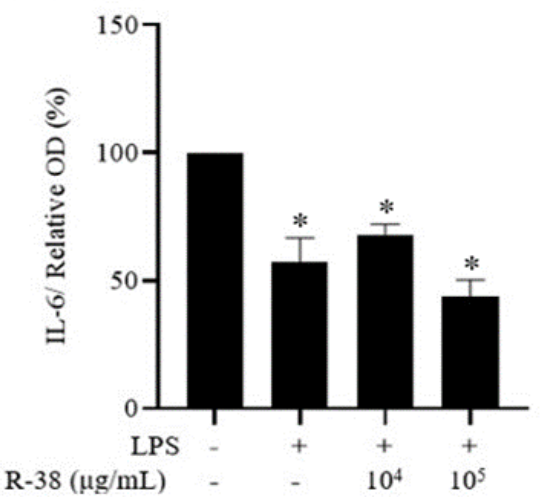

Figure 3 The effect of R-38TM water extract on the expression of inflammatory mediators in LPS-induced HSF1 184 cell line. (A) The percentage of TNF-a production. (B) The percentage of IL- 6 production. ${ }^{*} p<0.05$ vs control group 


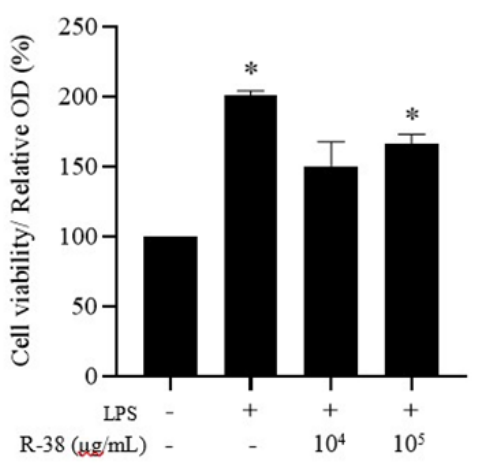

Figure 4 The effect of R-38 ${ }^{\mathrm{TM}}$ water extract on cell viability of LPS-induced HSF1 184 cell line. * $p<0.05$ vs control group

Many diseases arise from the deficiency or excess of a specific metabolite in the body. Xanthine oxidase (XO) is an enzyme to catalyze hypoxanthine and xanthine into uric acids [33]. Excessive serum uric acid in the body, also known as hyperuricemia, may result in monosodium urate crystals deposition in joints and kidneys, which subsequently trigger the occurrence of acute inflammation. Gout is a common metabolic disorder closely related to hyperuricemia. There are many modern medicines available for gouts such as XO inhibitors (allopurinol, febuxostat), uricosuric drugs (probenecid), cyclooxygenase-2 (COX-2) inhibitors, and nonsteroidal anti-inflammatory drugs (NSAIDs). Despite their therapeutic effect, they also cause undesirable side effects to the body [34]. For example, allopurinol is very effective to stop the formation of uric acid via inhibition of the XO activity. However, the body metabolism in urate production will become abnormal in the absence of $X O$. Thus, the present study investigated the effect of R-38TM water extract in the inhibition of $\mathrm{XO}$ activity. The results showed that the extract moderately inhibited $\mathrm{xO}$ activity as compared to allopurinol (Table 1), which fulfilled the body requirement in maintaining the $\mathrm{XO}$ activity.

COX-2 and prostaglandins are associated with inflammatory diseases including arthritis as they are the mediators responsible for the progression of an inflammatory response [35]. Selective COX-2 inhibitor agents such as celecoxib and NSAIDs (e.g., indomethacin and diclofenac) are very effective drugs to inhibit COX-2 activity as well as produce anti-inflammatory, antipyretic, and analgesic activities [36]. Nevertheless, body functionality will be affected if COX-2 is lacking. Prostacyclin $\left(\mathrm{PGI}_{2}\right)$ also known as prostaglandin helps to relax the lining of the blood vessel and suppress platelet activation. The decrease in the amount of PGI2 may increase the risk of cardiovascular incidence due to coagulation of platelets and abnormal clotting [37]. The present study investigated the inhibitory effect of R-38 TM water extract on the COX-2 activity. The results found that R-38 ${ }^{\mathrm{TM}}$ water extract showed a moderate (34.41\%) COX-2 inhibition effect at $100 \mu \mathrm{g} / \mathrm{mL}$ (Table
1). Hence, based on the findings from both $X O$ and COX2 enzymes inhibition assay, it is suggested that the anti-hyperuricemic mechanism of R-38'M may involve in the inhibition of $\mathrm{XO}$ and the prostaglandin pathway.

Table 1 In vitro xanthine oxidase (XO) and cyclooxygenase2 (COX-2) inhibitory activity of R-38' ${ }^{\mathrm{TM}}$ water extract

\begin{tabular}{|c|c|c|c|c|c|c|}
\hline \multirow{2}{*}{$\begin{array}{l}\text { Sample } \\
\text { group } \\
(\mu \mathrm{g} / \mathrm{ml})\end{array}$} & \multicolumn{5}{|c|}{ Percentage of XO inhibition (\%) } & \multirow{2}{*}{$\begin{array}{l}\mathrm{IC}_{50} \\
(\mu \mathrm{g} / \mathrm{ml})\end{array}$} \\
\hline & 0.01 & 0.1 & 1 & 10 & 100 & \\
\hline R-38'M & 27.9 & 42.4 & 36.4 & 44.6 & 56.2 & \\
\hline $\begin{array}{l}\text { water } \\
\text { extract }\end{array}$ & $\begin{array}{c}8 \pm \\
3.31\end{array}$ & $\begin{array}{c}3 \pm \\
1.75\end{array}$ & $\begin{array}{c}4 \pm \\
8.99\end{array}$ & $\begin{array}{l}5 \pm \\
4.44\end{array}$ & $\begin{array}{c}3 \pm \\
1.23\end{array}$ & 27.22 \\
\hline \multirow{3}{*}{$\begin{array}{l}\text { Allopurinol } \\
\text { (positive } \\
\text { control) }\end{array}$} & 52.1 & 66.1 & 78.4 & 81.0 & 90.6 & \\
\hline & $\begin{array}{c}4 \pm \\
4.56\end{array}$ & $\begin{array}{c}9 \pm \\
3.55\end{array}$ & $\begin{array}{c}2 \pm \\
4.07\end{array}$ & $\begin{array}{c}0 \pm \\
9.85\end{array}$ & $\begin{array}{c}0 \pm \\
0.60\end{array}$ & $<0.01$ \\
\hline & \multicolumn{5}{|c|}{ Percentage of COX-2 inhibition (\%) } & \\
\hline$R-38^{T M}$ & 36.1 & 40.4 & 37.1 & 40.1 & 34.4 & \\
\hline water & $8 \pm$ & $6 \pm$ & $2 \pm$ & $5 \pm$ & $1 \pm$ & - \\
\hline extract & 0.49 & 1.45 & 3.45 & 1.04 & 1.81 & \\
\hline
\end{tabular}

Unknown concentration of celecoxib was provided in the kit as a positive control with \% inhibition of $79.18 \pm 2.15$

Values are expressed as mean \pm Standard deviation.

R-38 ${ }^{\mathrm{TM}}$ is an innovative polyherbal medicine developed through the Malay wisdom in traditional herbal medicine. This formulation was traditionally used for treating health conditions related to inflammation of joints, bones, and nerves. Though many previous studies have reported on the safety of each herb, there is no available research on the safety of this polyherbal formulation. In the present study, in vitro and in vivo studies on the R-38 ${ }^{\mathrm{TM}}$ water extract were carried out to determine the toxicity potential of R-38TM. The in vitro test was conducted to determine the cytotoxicity potential of R-38 ${ }^{\mathrm{T} M}$ against the HSF1184 cell line. According to the National Institutes of Health [38], the LD50 (50\% lethal dose) value for safety study on laboratory animals (i.e., rodents) can be estimated from the $\mathrm{IC}_{50}$ value obtained from in vitro cytotoxicity test. This approach provides a starting dose closer to the actual LD50 value for in vivo acute oral toxicity study. From this study, the water extract of R-38 ${ }^{\mathrm{TM}}$ has no LD 50 value as there was no inhibitory effect seen in the cytotoxicity assay. Thus, the selected starting dose for acute oral toxicity study was $300 \mathrm{mg} / \mathrm{kg}$ as suggested by the OECD 420 guideline. The starting dose of this guideline is within the safety range of $\mathrm{R}-38^{\mathrm{TM}}$ based on the results obtained.

The in vivo safety study of the R-38 ${ }^{\mathrm{TM}}$ water extract was investigated through acute and subacute oral toxicity study on SD female rats following the OECD guidelines. The OECD guideline suggested a predetermined fixed dose, and from the outcome, a test substance is ranked and classified according to the Globally Harmonized System (GHS) [39]. The acute oral toxicity study was carried out on 15 female SD 
rats tested with a single oral dose of R-38TM water extract at $300 \mathrm{mg} / \mathrm{kg}$ and $2000 \mathrm{mg} / \mathrm{kg}$. The findings revealed that the water extract did not exhibit any toxicity effects, sudden death, or mortality. The body weight changes of all rats (Table S1) showed no significant difference $(p>0.05)$ as compared to the control group, which indicated that the treatment of R-38TM water extract did not obstruct the growth of rats even up to the highest dose of $2000 \mathrm{mg} / \mathrm{kg}$. There was also no significant difference $(p>0.05)$ in the absolute and relative organ weight (Table S2).

The hematological (Table S3) and biochemical analysis (Table S4) on treatment I ( $300 \mathrm{mg} / \mathrm{kg}$ ) had shown no treatment-related toxicity effects, but treatment II $(2000 \mathrm{mg} / \mathrm{kg})$ showed a significant increase $(p<0.05)$ in WBC counts and decrease in albumin level. Regardless, the common markers of toxicity which were the liver profile (ALT, AST, and ALP) and kidney profile (creatinine and BUN) showed no significant $(p>0.05)$ alterations. It is most likely that the significant differences were caused by withingroup variation. The histopathological evaluation also showed no treatment-related morphological alterations in the liver and kidneys of all the treatments after a single dose of R-38 ${ }^{\mathrm{TM}}$ water extract (Figure S1). It caused no significant ( $p>0.05$ ) organ damage and occurrence of macroscopic and microscopic changes. The $L_{50}$ of R-38 $8^{\mathrm{TM}}$ water extract was estimated to be more than $2000 \mathrm{mg} / \mathrm{kg}$ by oral administration. Herbal medicines with $L_{50}$ values greater than $2000 \mathrm{mg} / \mathrm{kg}$ were considered safe for acute exposure [40-41].

The study of subacute oral toxicity was conducted on four groups of rats treated with a repeated daily oral dose of $300 \mathrm{mg} / \mathrm{kg}, 1000 \mathrm{mg} / \mathrm{kg}$, and $2000 \mathrm{mg} / \mathrm{kg}$ of R-38 $8^{\mathrm{TM}}$ water extract and vehicle for 28 days. The findings of this study revealed that the R-38 ${ }^{\mathrm{TM}}$ water extract was well tolerated and did not obstruct the growth of all the treated rats even up to the highest dose of $2000 \mathrm{mg} / \mathrm{kg}$ (Table S5). The absolute and relative organ weight of all treated rats were found to be statistically insignificant $(p>0.05)$ with respect to the control group (Table S6). All hematological parameters of the three treatment groups were well within the normal limits as compared to the control group (Table 2). The biochemical analysis of all treated groups also showed no significant differences as compared to the control group (Table 3). The histopathological analysis on the liver and kidney of the three treatment groups revealed no treatment-related abnormalities in the cell morphology (Figure 5 and Figure 6). The satellite treatment group $(2000 \mathrm{mg} / \mathrm{kg})$ was maintained for another 14 days in the recovery period to observe potential recovery or delayed toxicity events. Consequently, the findings revealed no mortality or occurrence of any delayed toxicity events in all assessments.

Table 2 Haematological values of SD rats orally administrated with R-38 ${ }^{\mathrm{TM}}$ water extract in the 28 -day repeated oral dose study and recovery period.

\begin{tabular}{|c|c|c|c|c|c|c|}
\hline \multirow{2}{*}{ Parameter } & \multicolumn{6}{|c|}{ Dose $(\mathrm{mg} / \mathrm{kg})$} \\
\hline & Control & 300 & 1000 & 2000 & Control RP & 2000 RP \\
\hline WBC (x109/L) & $7.9 \pm 3.78$ & $7.9 \pm 2.01$ & $9.7 \pm 2.63$ & $10.6 \pm 2.22$ & $8.8 \pm 3.25$ & $7.9 \pm 3.86$ \\
\hline $\mathrm{RBC}\left(\times 10^{12} / \mathrm{L}\right)$ & $6.5 \pm 0.84$ & $6.6 \pm 0.16$ & $6.5 \pm 0.39$ & $6.7 \pm 0.84$ & $6.4 \pm 0.51$ & $6.7 \pm 0.52$ \\
\hline $\begin{array}{l}\text { Haemoglobfin } \\
\text { (g/dL) }\end{array}$ & $12.8 \pm 1.62$ & $13.8 \pm 0.35$ & $13.6 \pm 0.50$ & $12.7 \pm 1.01$ & $12.9 \pm 1.17$ & $12.8 \pm 0.38$ \\
\hline $\begin{array}{l}\text { Haematocrit } \\
\text { (\%) }\end{array}$ & $37.75 \pm 4.99$ & $38.25 \pm 0.96$ & $37.25 \pm 1.71$ & $36.60 \pm 3.85$ & $37.00 \pm 2.55$ & $37.40 \pm 1.95$ \\
\hline$M C V(f l)$ & $58.0 \pm 0.82$ & $58.3 \pm 2.06$ & $57.5 \pm 1.00$ & $54.8 \pm 2.86$ & $58.4 \pm 2.07$ & $56.4 \pm 2.19$ \\
\hline $\mathrm{MCH}(\mathrm{pg})$ & $19.8 \pm 1.50$ & $21.0 \pm 0.82$ & $21.0 \pm 0.00$ & $19.2 \pm 1.64$ & $20.4 \pm 1.14$ & $19.2 \pm 1.30$ \\
\hline $\mathrm{MCHC}(\mathrm{g} / \mathrm{L})$ & $340.0 \pm 24.49$ & $362.5 \pm 5.00$ & $365.0 \pm 5.77$ & $348.0 \pm 17.89$ & $348.0 \pm 13.04$ & $342.0 \pm 13.04$ \\
\hline $\begin{array}{l}\text { Platelets } \\
\text { (x109/L) }\end{array}$ & $700.0 \pm 335.83$ & $1018.0 \pm 196.96$ & $762.5 \pm 74.84$ & $614.0 \pm 177.65$ & $884.8 \pm 136.64$ & $838.0 \pm 111.59$ \\
\hline Neutrophils (\%) & $33.3 \pm 9.91$ & $30.3 \pm 9.18$ & $28.5 \pm 13.08$ & $27.4 \pm 18.53$ & $29.4 \pm 8.38$ & $43.4 \pm 17.30$ \\
\hline $\begin{array}{l}\text { Lymphocytes } \\
\text { (\%) }\end{array}$ & $60.8 \pm 10.72$ & $66.0 \pm 9.06$ & $67.0 \pm 11.34$ & $69.2 \pm 20.97$ & $62.6 \pm 6.50$ & $50.6 \pm 18.93$ \\
\hline Eosinophils (\%) & $3.3 \pm 2.36$ & $1.5 \pm 1.73$ & $1.8 \pm 1.50$ & $1.0 \pm 1.73$ & $4.6 \pm 2.79$ & $3.4 \pm 2.30$ \\
\hline Monocytes (\%) & $2.5 \pm 0.58$ & $2.3 \pm 1.71$ & $2.8 \pm 2.22$ & $2.4 \pm 1.67$ & $3.2 \pm 2.49$ & $2.6 \pm 1.14$ \\
\hline Basophils (\%) & $0.0 \pm 0.00$ & $0.0 \pm 0.00$ & $0.0 \pm 0.00$ & $0.0 \pm 0.00$ & $0.0 \pm 0.00$ & $0.0 \pm 0.00$ \\
\hline
\end{tabular}

Values are expressed as mean \pm Standard deviation ( $n=5$; for each group). RP: Recovery period; RBC: red blood cell count; WBC: white blood cell count; MCV: mean corpuscular volume; $\mathrm{MCH}$ : mean corpuscular haemoglobin; $\mathrm{MCHC}$ : mean corpuscular haemoglobin concentration 
Table 3 Serum biochemical parameters of SD rats orally administrated with R-38тM water extract in the 28-day repeated oral dose study and recovery period

\begin{tabular}{|c|c|c|c|c|c|c|}
\hline \multirow{2}{*}{ Parameter } & \multicolumn{6}{|c|}{ Dose (mg/kg) } \\
\hline & Control & 300 & 1000 & 2000 & Control RP & $2000 \mathrm{RP}$ \\
\hline AST (U/L) & $207.6 \pm 130.78$ & $153.8 \pm 23.21$ & $215.6 \pm 53.97$ & $132.8 \pm 18.28$ & $204.0 \pm 76.72$ & $149.0 \pm 30.86$ \\
\hline ALT (U/L) & $74.2 \pm 44.86$ & $70.4 \pm 7.70$ & $65.0 \pm 19.20$ & $42.8 \pm 7.16$ & $75.6 \pm 11.06$ & $60.8 \pm 9.65$ \\
\hline ALP (U/L) & $197.6 \pm 55.30$ & $212.2 \pm 89.91$ & $157.6 \pm 32.34$ & $132.8 \pm 55.36$ & $166.8 \pm 49.33$ & $130.4 \pm 116.67$ \\
\hline Urea (mmol/L) & $8.2 \pm 1.30$ & $8.4 \pm 0.78$ & $8.0 \pm 0.38$ & $7.5 \pm 1.29$ & $8.3 \pm 0.99$ & $7.9 \pm 0.72$ \\
\hline Creatinine $(\mu \mathrm{mol} / \mathrm{L})$ & $56.1 \pm 4.1$ & $62.8 \pm 4.11$ & $62.0 \pm 3.15$ & $59.3 \pm 5.30$ & $59.0 \pm 7.26$ & $59.7 \pm 3.20$ \\
\hline BUN (mmol/L) & $8.2 \pm 1.30$ & $8.4 \pm 0.78$ & $8.0 \pm 0.38$ & $7.5 \pm 1.29$ & $8.3 \pm 0.99$ & $7.9 \pm 0.72$ \\
\hline Uric acid ( $\mu \mathrm{mol} / \mathrm{L})$ & $125.6 \pm 17.43$ & $145.9 \pm 47.95$ & $130.4 \pm 42.79$ & $141.1 \pm 27.92$ & $138.7 \pm 40.87$ & $120.8 \pm 16.05$ \\
\hline Total protein (g/L) & $77.4 \pm 3.78$ & $79.2 \pm 3.63$ & $69.6 \pm 3.21$ & $70.4 \pm 4.98$ & $79.4 \pm 6.02$ & $80.2 \pm 4.15$ \\
\hline Albumin (g/L) & $30.0 \pm 4.53$ & $33.0 \pm 2.45$ & $27.2 \pm 1.10$ & $29.8 \pm 2.17$ & $34.4 \pm 4.34$ & $33.2 \pm 1.64$ \\
\hline Globulin (g/L) & $47.4 \pm 7.20$ & $46.2 \pm 3.35$ & $42.4 \pm 2.30$ & $40.6 \pm 4.04$ & $45.0 \pm 3.32$ & $47.0 \pm 2.65$ \\
\hline $\begin{array}{l}\text { Total cholesterol } \\
(\mathrm{mmol} / \mathrm{L})\end{array}$ & $1.6 \pm 0.29$ & $1.8 \pm 0.21$ & $1.5 \pm 0.34$ & $1.5 \pm 0.18$ & $2.0 \pm 0.51$ & $2.2 \pm 0.47$ \\
\hline $\begin{array}{l}\text { Triglycerides } \\
\text { (mmol/L) }\end{array}$ & $1.4 \pm 0.78$ & $1.5 \pm 0.36$ & $1.6 \pm 0.44$ & $1.3 \pm 0.65$ & $1.8 \pm 0.41$ & $1.1 \pm 0.43$ \\
\hline Glucose (mmol/L) & $11.4 \pm 2.85$ & $14.1 \pm 3.39$ & $14.9 \pm 3.41$ & $12.2 \pm 4.35$ & $10.1 \pm 2.43$ & $7.9 \pm 1.55$ \\
\hline
\end{tabular}

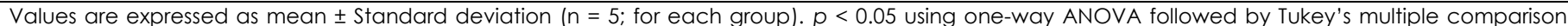

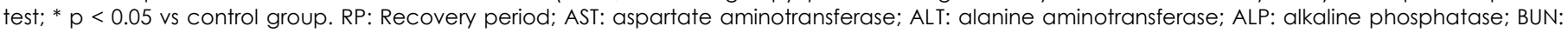
blood urea nitrogen

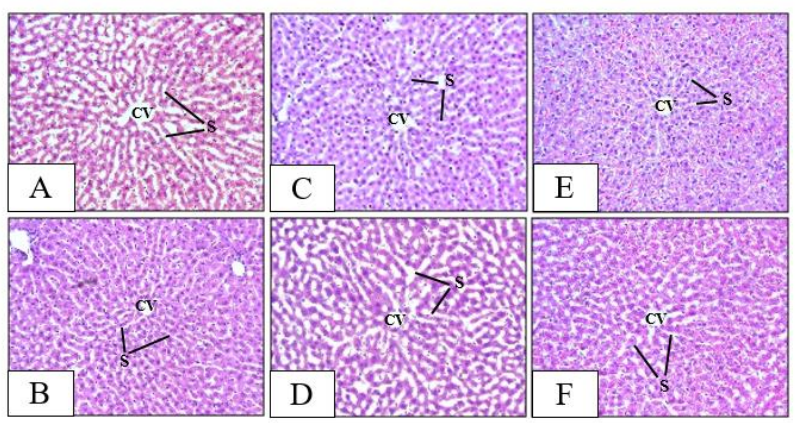

Figure 5 Photomicrographs of paraffin section of liver stained with H\&E in subacute oral toxicity study (Magnification 200x). (A) Liver treated with $300 \mathrm{mg} / \mathrm{kg}$ bw; (B) Liver treated with $1000 \mathrm{mg} / \mathrm{kg}$ bw; (C) Liver treated with $2000 \mathrm{mg} / \mathrm{kg}$ bw; (D) Liver of satellite rat treated with 2000 $\mathrm{mg} / \mathrm{kg} \mathrm{bw}$; (E) Liver of rat in control group; (F) Liver in satellite control group. CV - central vein; $\mathrm{S}$ - sinusoid

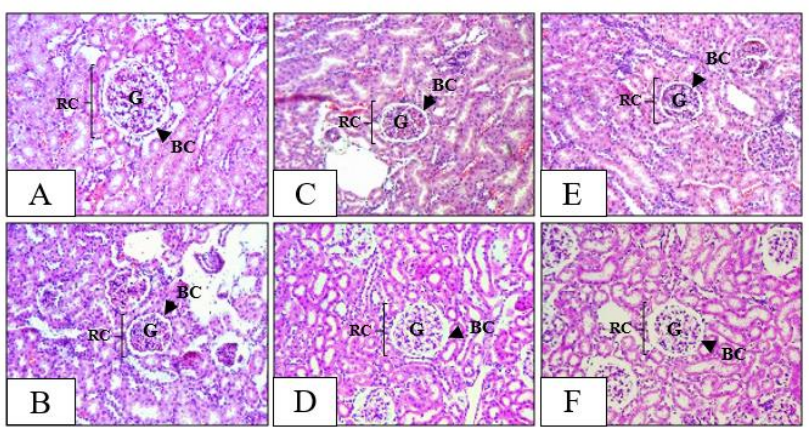

Figure 6 Photomicrographs of paraffin section of the kidney stained with H\&E in subacute oral toxicity study (Magnification 200x). (A) Kidney treated with $300 \mathrm{mg} / \mathrm{kg}$ bw; (B) Kidney treated with $1000 \mathrm{mg} / \mathrm{kg}$ bw; (C) Kidney treated with $2000 \mathrm{mg} / \mathrm{kg}$ bw; (D) Kidney of satellite rat treated with $2000 \mathrm{mg} / \mathrm{kg}$ bw; (E) Kidney in control group; (F) Kidney in satellite control group. RC - Renal corpuscle; BC-Bowman's capsule; G-glomerulus

\subsection{CONCLUSION}

In sum, the in vitro study revealed that R-38 $8^{\mathrm{TM}}$ water extract inhibited the production of IL-6 and TNF-a in the LPS-induced fibroblast cells. Furthermore, the water extract might potentially treat the arthritis related-conditions by its ability to moderately inhibit the XO and COX-2 activities. The R-38 ${ }^{\mathrm{TM}}$ water extract also caused no cytotoxic effect on fibroblast cells up to the highest dose of $2000 \mathrm{mg} / \mathrm{kg}$, however, its $1 C_{50}$ value could not be determined. The studies of acute and subacute oral toxicity of R-38 ${ }^{\mathrm{TM}}$ water extract did not exhibit any treatment-related toxicity at all doses. The $L_{50}$ value of the R-38 ${ }^{\text {TM }}$ water extract was estimated to be more than $2000 \mathrm{mg} / \mathrm{kg}$. The R-38TM showed potential anti-inflammatory activity and can be considered as a promising therapeutic medicine against pro-inflammatory diseases including arthritis. The present findings could serve as preliminary data for a long-term toxicity study, which is necessary to further evaluate the efficacy and safety of R-38 ${ }^{\mathrm{TM}}$.

\section{Acknowledgements}

The authors wish to thank Ministry of Higher Education for funding the research activities under the MyGRANTS project Fundamental Research Grant Scheme (FRGS) No. 10511 and Naturemedics Laboratories (NML) Sdn. Bhd. for supplying raw materials of R-38TM. The authors also acknowledge Romlianawati Mohd Sharazlee and $\mathrm{Ng} \mathrm{Hui} \mathrm{Ci}$ for contributing in this research. 


\section{References}

[1] Guo, Q., Y. Wang, D. Xu, J. Nossent, N. J. Pavlos, \& J. Xu. 2018. Rheumatoid Arthritis: Pathological Mechanisms and Modern Pharmacologic Therapies. Bone Research. 6(1): 114.

[2] Thomson, P., J. Jones, J. M. Evans, \& S. L. Leslie. 2012. Factors Influencing the Use of Complementary and Alternative Medicine and Whether Patients Inform Their Primary Care Physician. Complementary Therapies in Medicine. 20(1-2): 45-53.

[3] Khan, M. S. A., \& I. Ahmad. 2019. New Look to Phytomedicine: Chapter 1-Herbal Medicine: Current Trends and Future Prospects. London, United Kingdom: Elsevier Inc. Academic Press. 3-13.

[4] Arafat, O. M., S. Y. Tham, A. Sadikun, I. Zhari, P. J. Haughton, \& M. Z. Asmawi. 2008. Studies on Diuretic and Hypouricemic Effects of Orthosiphon stamineus Methanol Extracts in Rats. Journal of Ethnopharmacology. 118(3): 354-360.

[5] Subramanian, P. \& M. Nishan. 2015. Biological Activities Of Greater Galangal, Alpinia galanga. Research \& Reviews: Journal of Botanical Science- Special Issue, Phytopathology/ Genes \& Diseases. S1.

[6] Zhou, Y. Q., H. Liu, M. X. He, R. Wang, Q. Q. Zeng, Y. Wang, W. C. Ye, \& Q. W. Zhang. 2018. A Review of the Botany, Phytochemical, and Pharmacological Properties of Galangal. Chapter 11-Natural and Artificial Flavoring Agents and Food Dyes. London, United Kingdom: Elsevier Inc. Academic Press. 351-396.

[7] Phitak, T., K. Choocheep, P. Pothacharoen, W. Pompimon, B. Premanode, \& P. Kongtawelert. 2009. The Effects of phydroxycinnamaldehyde from Alpinia galanga extracts on Human Chondrocytes. Phytochemistry. 70(2): 237-243.

[8] Kaushik, M. L. \& S. S. Jalalpure. 2011. Effect of Curcuma zedoaria Rosc Root Extracts on Behavioral and Radiology Changes in Arthritic Rats. Journal of Advanced Pharmaceutical Technology \& Research. 2(3): 170.

[9] Devaraj, S., A. S. Esfahani, S. Ismail, S. Ramanathan, \& M. F. Yam. 2010. Evaluation of the Antinociceptive Activity and Acute Oral Toxicity of Standardized Ethanolic Extract of the Rhizome of Curcuma xanthorrhiza Roxb. Molecules. 15(4): 2925-2934.

[10] Unnisa, A. \& T. D. Parveen. 2011. Anti-inflammatory and Acute Toxicity Studies of the Extracts from the Rhizomes of Alpinia galanga Willd. Der Pharmacia Sinica. 2(2): 361-367.

[11] Antro Jennie, X., S. Tripathy, K. Ramya, K. Srinivas, \& K. S. Kumar. 2016. Evaluation of Anti-arthritic Potential of elephantopus scaber in Complete Freund's Adjuvant Induced Arthritic Rat Model. International Journal of Phytopharmacology. 7(1): 41-45.

[12] Kim, S., K. E. Kook, C. Kim, \& J. K. Hwang. 2018. Inhibitory Effects of Curcuma xanthorrhiza Supercritical Extract and xanthorrhizol on LPS-induced Inflammation in HGF-1 Cells and RANKL-induced Osteoclastogenesis in RAW264.7 Cells. Journal of Microbiology and Biotechnology. 28(8): 1270-1281.

[13] Lee, T. K., T. A. Trinh, S. R. Lee, S. Kim, H. M. So, E. Moon, G. S. Hwang, K. S. Kang, J. H. Kim, N. Yamabe, \& K. H. Kim. 2019. Bioactivity-based Analysis and Chemical Characterization of Anti-inflammatory Compounds from Curcuma zedoaria Rhizomes using LPS-stimulated RAW264.7 Cells. Bioorganic Chemistry. 82: 26-32.

[14] Zhang, L., X. Liang, Z. Ou, M. Ye, Y. Shi, Y. Chen, J. Zhao, D. Zheng, \& H. Xiang. 2020. Screening of Chemical Composition, Anti-arthritis, Antitumor and Antioxidant Capacities of Essential Oils from Four Zingiberaceae Herbs. Industrial Crops and Products. 149: 112342.

[15] Yam, M. F., R. Basir, M. Z. Asmawi, M. Z., \& Z. Ismail. 2007. Antioxidant and Hepatoprotective Effects of Orthosiphon stamineus Benth. Standardized Extract. The American Journal of Chinese Medicine. 35(1): 115-126.
[16] Tabana, Y. M., F. S. R. Al-Suede, M. B. K. Ahamed, S. S. Dahham, L. E. A Hassan, S. Khalilpour, M. Taleb-Agha, D. Sandai, A. S. A. Majid, \& A. M. S. A Majid. 2016. Cat's Whiskers (Orthosiphon stamineus) Tea Modulates Arthritis Pathogenesis via the Angiogenesis and Inflammatory Cascade. BMC Complementary and Alternative Medicine. 16(1): 1-11.

[17] Bokhari, R. A., N. A. C. A. Tantowi, S. F. Lau, \& S. Mohamed. 2018. Java Tea (Orthosiphon stamineus) Protected against Osteoarthritis by Mitigating Inflammation and Cartilage Degradation: A Preclinical Study. Inflammopharmacology. 26(4): 939-949.

[18] Gautam, R. K., G. Gupta, S. Sharma, K., Hatware, K. Patil, K. Sharma, S. Goyal, D. K. Chellappan, \& K. Dua. 2019. Rosmarinic Acid Attenuates Inflammation in Experimetntally Induced Arthritis in Wistar Rats, using Freund's Complete Adjuvant. International Journal of Rheumatic Diseases. 22(7): 1247-1254.

[19] Das, R. J., N. J. Duragkar, M. J. Umekar, \& P. Katolkar. 2017. Evaluation of Anti-inflammatory Activity of Different Extracts of Alpinia galanga. Research Journal of Pharmacy and Technology. 10(10): 3301-3304.

[20] Kaushik, M. \& S. S. Jalalpure. 2011. Anti-inflammatory Efficacy of Curcuma zedoaria Rosc Root Extracts. Asian Journal of Pharmaceutical Clinical Research. 4(3): 90-92.

[21] Mohamed, E. A. H., C. P. Lim, O. S. Ebrika, M. Z. Asmawi, A. Sadikun, \& M. F. Yam. 2011. Toxicity Evaluation of a Standardised $50 \%$ Ethanol Extract of Orthosiphon stamineus. Journal of Ethnopharmacology. 133(2): 358363.

[22] Chin, J. H., H. H. Abas, \& I. Sabariah. 2008. Toxicity Study of Orthosiphon stamineus Benth (Misai Kucing) on Sprague Dawley Rats. Tropical Biomedicine. 25(1): 9-16.

[23] Akowuah, G. A., I. Zhari, I. Norhayati, A. Sadikun, \& S. M. Khamsah. 2004. Sinensetin, Eupatorin, 3'-hydroxy-5, 6, 7, 4'tetramethoxyflavone and Rosmarinic Acid Contents and Antioxidative Effect of Orthosiphon stamineus from Malaysia. Food Chemistry. 87(4): 559-566.

[24] Patel, S., N. Gheewala, A. Suthar, \& A. Shah. 2009. In-vitro Cytotoxicity Activity of Solanum nigrum Extract against HeLa Cell Line and Vero Cell Line. International Journal of Pharmacy and Pharmaceutical Sciences. 1(S1): 38-46.

[25] Zdařilová, A., A. Svobodová, V. Šimánek, \& J. Ulrichová. 2009. Prunella vulgaris Extract and Rosmarinic Acid Suppress Lipopolysaccharide-induced Alteration in Human Gingival Fibroblasts. Toxicology in Vitro. 23(3): 386392.

[26] Li, Y., C. M. Frenz, Z. Li, M. Chen, Y. Wang, F. Li, C. Luo, J. Sun, L. Bohlin, Z. Li, \& H. Yang. 2011. Virtual and In Vitro Bioassay Screening of Phyłochemical Inhibitors from Flavonoids and Isoflavones against Xanthine Oxidase and Cyclooxygenase-2 for Gout Treatment. Chemical Biology \& Drug Design. 81 (4): 537-44.

[27] Organization for Economic Co-operation and Development (OECD). 2001. Guidelines for Testing of Chemicals, Acute Oral Toxicity-fixed Dose Procedure. OECD Guideline for the Testing of Chemicals. Section 4: Health Effects.

[28] Organization for Economic Co-operation and Development (OECD). 2008. Repeated Dose 28-day Oral Toxicity Study in Rodents. OECD Guideline for the Testing of Chemicals. Section 4: Health Effects.

[29] Zainol, S. N., Fadhlina, A., Rentala, S. V., Pillai, R., Yalaka M., Bansal, I., Surender, E., Vatsavai, L. K., Eswarappa, R., Ismail, H. F. \& Majid, F. A. A. 2021. Analytical Method Cross Validation by HPLC for Identification of Five Markers and Quantification of One Marker in SynacinnTM Formulations and Its in Vivo Bone Marrow Micronucleus Test Data. Data in Brief. 36: 107001.

[30] Nam, J. S., S. Jagga, A. R. Sharma, J. H. Lee, J. B. Park, J. S. Jung, \& S. S. Lee. 2017. Anti-inflammatory Effects of Traditional Mixed Extract of Medicinal Herbs (MEMH) on Monosodium Urate Crystal-induced Gouty 
Arthritis. Chinese Journal of Natural Medicines. 15(8): 561575.

[31] Dong, Z. B., Y. H. Zhang, B. J. Zhao, C. Li, G. Tian, B. Niu, H. Qi, L. Feng, \& J. G. Shao. 2015. Screening for Antiinflammatory Components from Corydalis bungeana Turcz based on Macrophage Binding Combined with HPLC.BMC Complementary and Alternative Medicine. 15(1): 1-10.

[32] Kim, M. B., C. Kim, Y. Song, \& J. K. Hwang. 2014. Antihyperglycemic and Anti-inflammatory Effects of Standardized Curcuma xanthorrhiza Roxb. Extract and its Active Compound xanthorrhizol in High-fat Diet-induced Obese Mice. Evidence-based Complementary and Alternative Medicine. 2014: 205915.

[33] Liu, X., R. Chen, Y. Shang, B. Jiao, \& C. Huang. 2008. Lithospermic Acid as a Novel Xanthine Oxidase Inhibitor has Anti-inflammatory and Hypouricemic Effects in Rats. Chemico-Biological Interactions. 176(2-3): 137-142.

[34] Abu Bakar, F. I., M. F Abu Bakar, A. Rahmat, N. Abdullah, S. F. Sabran, \& S. Endrini. 2018. Anti-gout Potential of Malaysian Medicinal Plants. Frontiers in Pharmacology. 9: 261.

[35] Attiq, A., J. Jalii, K. Husain, \& W. Ahmad. 2018. Raging the War against Inflammation with Natural Products. Frontiers in Pharmacology. 9: 976.
[36] Zarghi, A. \& S. Arfaei. 2011. Selective COX-2 Inhibitors: A Review of Their Structure-Activity Relationships. Iranian Journal of Pharmaceutical Research. 10(4): 655-683.

[37] Martinez-Gonzalez, J. \& L. Badimon. 2007. Mechanisms Underlying the Cardiovascular Effects of COX-inhibition: Benefits and Risks. Current Pharmaceutical Design. 13(22): 2215-2227.

[38] National Institutes of Health. 2006. Background Review Document (BRD): Validation of Neutral Red Uptake Test Methods NIH. In Vitro Cytotoxicity Test Methods for Estimating Acute Oral Systemic Toxicity.

[39] Roopashree, T. S., R. Dang, R. H. Shobha Rani, \& C. Narendra. 2009. Acute Oral Toxicity Studies of Antipsoriatic Herbal Mixture Comprising of Aqueous Extracts of Calendula officinalis, Momordica charantia, Cassia tora and Azadirachta indica Seed Oil. Thai Journal of Pharmaceutical Sciences. 33: 74-83.

[40] Nath, P. \& A. K. Yadav. 2015. Acute and Sub-acute Oral Toxicity Assessment of the Methanolic Extract from Leaves of Hibiscus rosa-sinensis L. in mice. Journal of Intercultural Ethnopharmacology. 4(1): 70.

[41] Awang, A. F. I., Ferdosh, S., Sarker, Z. I., I Sheikh, H., Ghafoor, K. and Yunus, K. 2016. Stereospermum fimbriatum as a Potential Source of Phytochemicals: A Review of Stereospermum Genus. Current Pharmaceutical Biotechnology. 17(12): 1024-1035. 


\section{Appendix}
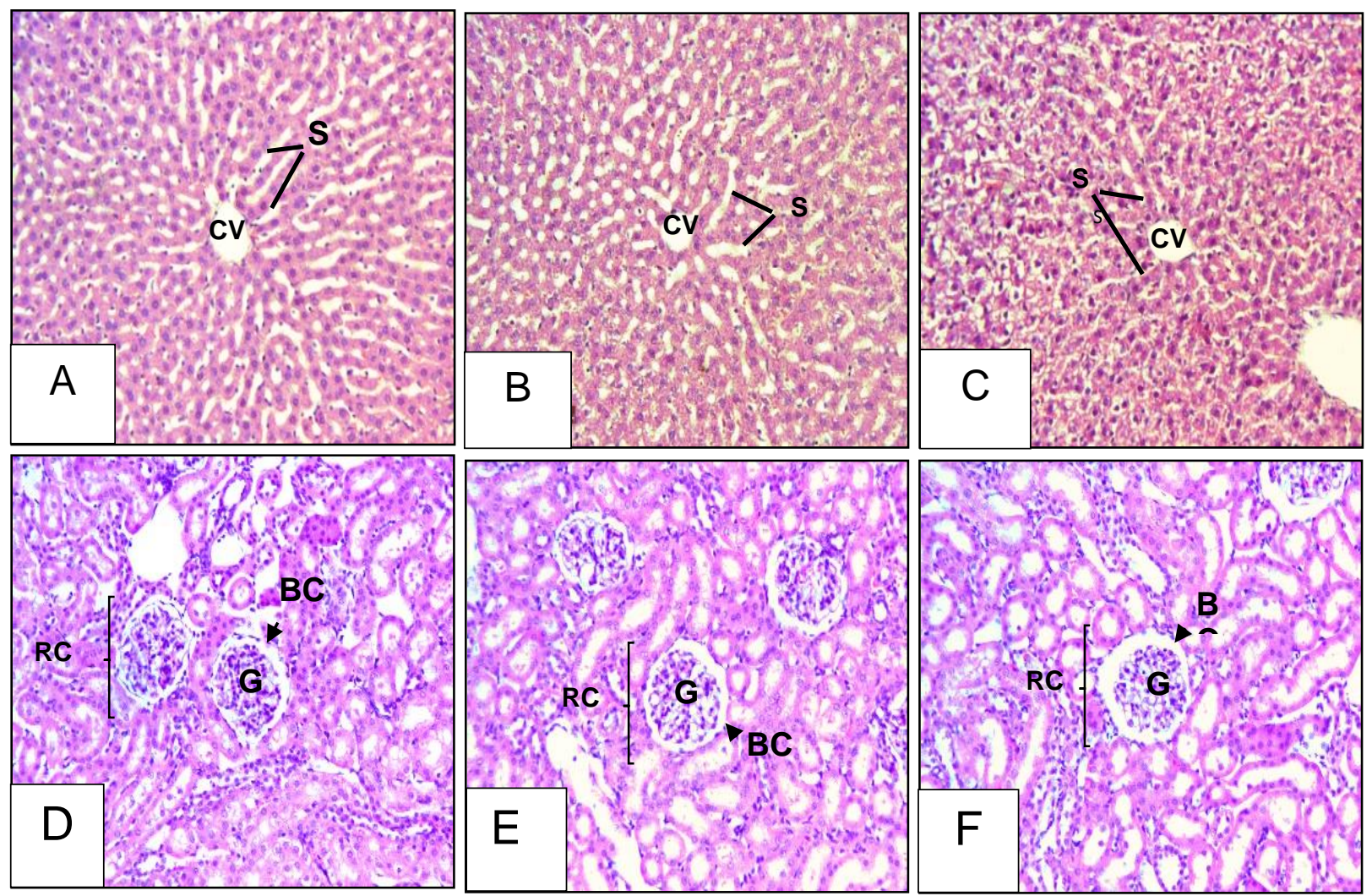

Figure S1 Photomicrographs of paraffin section of the liver and kidney stained with Haematoxylin \& Eosin (H\&E) solution in acute oral toxicity study (Magnification 200x). (A) Normal liver structure of control group; (B) Liver treated with $300 \mathrm{mg} / \mathrm{kg}$ bw; (C) Liver treated with $2000 \mathrm{mg} / \mathrm{kg}$ bw. (D) Normal kidney structure of control group; (E) Kidney treated with $300 \mathrm{mg} / \mathrm{kg}$ bw; (F) Kidney treated with 2000 mg/kg bw. CV: Central vein; BC: Bowman's capsule; S: Sinusoid; G: Glomerulus; RC: Renal corpuscle

Table S1 Body weight of CD rats orally administered with R-38 ${ }^{\mathrm{TM}}$ water extract in the acute oral toxicity study

\begin{tabular}{lccc}
\hline Group & Dose level & $\begin{array}{c}\text { Body Weight pre-treatment }(\mathbf{g}) ; \\
(\boldsymbol{n}=\mathbf{5})\end{array}$ & $\begin{array}{c}\text { Body Weight 14 days post-treatment } \\
(\mathbf{g}) ;(\boldsymbol{n}=\mathbf{5})\end{array}$ \\
\hline Control & $2 \mathrm{ml}$ distilled water & $194.0 \pm 8.94$ & $210.0 \pm 10.00$ \\
Treatment I & $300 \mathrm{mg} / \mathrm{kg} \mathrm{bw}$ & $192.0 \pm 17.89$ & $208.0 \pm 21.68$ \\
Treatment II & $2000 \mathrm{mg} / \mathrm{kg} \mathrm{bw}$ & $190.0 \pm 14.14$ & $222.0 \pm 27.75$ \\
\hline
\end{tabular}

Values are expressed as mean \pm Standard deviation ( $n=5$; for each group); $n=$ number of rats.

Table S2 Absolute and relative organ weight of CD rats following a single dose oral administration with $\mathrm{R}-38^{\mathrm{TM}}$ water extract

\begin{tabular}{lcccccc}
\hline $\begin{array}{l}\text { Dose } \\
(\mathbf{m g} / \mathbf{k g ~ b w})\end{array}$ & \multicolumn{2}{c}{ Control } & \multicolumn{2}{c}{$\mathbf{3 0 0}$} & \multicolumn{2}{c}{$\mathbf{2 0 0 0}$} \\
\hline Organ & Absolute (g) & Relative (\%) & Absolute (g) & Relative (\%) & Absolute (g) & Relative (\%) \\
Liver & $7.792 \pm$ & $3.723 \pm 0.4309$ & $7.930 \pm 0.9713$ & $3.810 \pm 0.2006$ & $8.126 \pm 0.9453$ & $3.609 \pm$ \\
& 0.6906 & & & & 0.6239 \\
Kidney & $1.436 \pm$ & $0.687 \pm 0.0810$ & $1.376 \pm 0.2215$ & $0.662 \pm 0.0837$ & $1.578 \pm 0.2146$ & $0.714 \pm$ \\
& 0.1106 & & & & & 0.0846 \\
\hline
\end{tabular}

Values are expressed in mean \pm Standard deviation ( $n=5$; for each group). 
Table \$3 Haematological parameters of CD rats after a single dose of R-38TM water extract

\begin{tabular}{|c|c|c|c|}
\hline \multirow{2}{*}{ Parameter } & \multirow[b]{2}{*}{ Control } & Dose (mg/kg bw) & \multirow[b]{2}{*}{2000} \\
\hline & & 300 & \\
\hline WBC (x109/L) & $4.83 \pm 1.25$ & $4.90 \pm 1.81$ & $9.10 \pm 3.81^{*}$ \\
\hline $\mathrm{RBC}\left(\times 10^{12} / \mathrm{L}\right)$ & $6.65 \pm 0.13$ & $6.60 \pm 0.52$ & $6.66 \pm 0.30$ \\
\hline Haemoglobin (g/dL) & $14.48 \pm 0.46$ & $13.83 \pm 0.96$ & $13.30 \pm 0.66$ \\
\hline Haematocrit (\%) & $39.25 \pm 1.71$ & $38.40 \pm 2.61$ & $37.60 \pm 0.89$ \\
\hline$M C V(f l)$ & $59.25 \pm 0.96$ & $58.40 \pm 0.89$ & $56.40 \pm 2.07$ \\
\hline $\mathrm{MCH}(\mathrm{pg})$ & $21.75 \pm 0.96$ & $21.20 \pm 0.45$ & $19.80 \pm 1.64$ \\
\hline $\mathrm{MCHC}(\mathrm{g} / \mathrm{L})$ & $370.0 \pm 14.14$ & $360.0 \pm 0.00$ & $356.0 \pm 20.74$ \\
\hline Platelets (x109/L) & $771.25 \pm 86.15$ & $659.00 \pm 342.94$ & $906.80 \pm 68.79$ \\
\hline Neutrophils (\%) & $44.0 \pm 10.10$ & $34.8 \pm 7.19$ & $34.8 \pm 5.76$ \\
\hline Lymphocytes (\%) & $53.3 \pm 9.91$ & $63.4 \pm 8.79$ & $60.6 \pm 4.39$ \\
\hline Eosinophils (\%) & $0.5 \pm 1.00$ & $0.2 \pm 0.45$ & $1.0 \pm 1.00$ \\
\hline Monocytes (\%) & $2.3 \pm 0.96$ & $1.6 \pm 1.34$ & $3.6 \pm 1.67$ \\
\hline Basophils (\%) & $0.0 \pm 0.00$ & $0.0 \pm 0.00$ & $0.0 \pm 0.00$ \\
\hline
\end{tabular}

Table S4 Serum Biochemical parameters of CD rats after a single dose of R-38 TM water extract

\begin{tabular}{|c|c|c|c|}
\hline \multirow{2}{*}{ Parameter } & \multirow[b]{2}{*}{ Control } & Dose (mg/kg bw) & \multirow[b]{2}{*}{2000} \\
\hline & & 300 & \\
\hline AST (U/L) & $175.40 \pm 66.53$ & $145.60 \pm 43.60$ & $180.80 \pm 31.56$ \\
\hline $\mathrm{ALT}(\mathrm{U} / \mathrm{L})$ & $69.40 \pm 24.42$ & $76.80 \pm 14.46$ & $71.40 \pm 19.01$ \\
\hline ALP (U/L) & $274.60 \pm 107.42$ & $259.80 \pm 127.09$ & $339.40 \pm 96.93$ \\
\hline Creatinine $(\mu \mathrm{mol} / \mathrm{L})$ & $61.78 \pm 2.88$ & $60.54 \pm 3.26$ & $57.55 \pm 5.62$ \\
\hline Urea (mmol/L) & $8.60 \pm 1.85$ & $7.89 \pm 0.61$ & $8.53 \pm 1.28$ \\
\hline BUN (mmol/L) & $8.60 \pm 1.85$ & $7.89 \pm 0.61$ & $8.53 \pm 1.28$ \\
\hline Uric acid ( $\mu \mathrm{mol} / \mathrm{L})$ & $131.56 \pm 19.72$ & $160.26 \pm 107.84$ & $137.54 \pm 11.19$ \\
\hline Total protein ( $\mathrm{g} / \mathrm{L})$ & $78.6 \pm 2.51$ & $75.8 \pm 6.91$ & $75.2 \pm 8.76$ \\
\hline Albumin $(\mathrm{g} / \mathrm{L})$ & $33.4 \pm 1.14$ & $32.6 \pm 2.61$ & $27.6 \pm 4.39 *$ \\
\hline Globulin (g/L) & $45.2 \pm 1.92$ & $43.2 \pm 4.55$ & $47.6 \pm 12.10$ \\
\hline Total cholesterol (mmol/L) & $1.86 \pm 0.065$ & $1.92 \pm 0.096$ & $1.58 \pm 0.348$ \\
\hline Triglyceride (mmol/L) & $1.626 \pm 1.2509$ & $1.694 \pm 0.8123$ & $1.888 \pm 0.4611$ \\
\hline Glucose (mmol/L) & $12.73 \pm 1.347$ & $13.38 \pm 4.738$ & $10.98 \pm 2.949$ \\
\hline
\end{tabular}

Values are expressed as mean \pm Standard deviation ( $n=5$; for each group).

$p<0.05$ using one-way ANOVA followed by Tukey's multiple comparison test; * $p<0.05$ vs control group.

AST: aspartate aminotransferase; ALT: alanine aminotransferase; ALP: alkaline phosphatase; BUN: blood urea nitrogen. 
Table S5 Body weight of SD rats orally administrated with R-38TM water extract in the 28-day repeated oral dose study and recovery period (satellite groups)

\begin{tabular}{|c|c|c|c|c|c|c|c|}
\hline Group & $\begin{array}{c}\text { Pre- } \\
\text { treatment } \\
\text { Weight }\end{array}$ & $\begin{array}{c}\text { BW Week } \\
1\end{array}$ & BW Week 2 & BW Week 3 & BW Week 4 & BW Week 5 & $\begin{array}{c}\text { BW } \\
\text { Week } 6\end{array}$ \\
\hline Control & $189.0 \pm 12.87$ & $\begin{array}{l}191.0 \pm \\
15.24\end{array}$ & $\begin{array}{c}193.0 \pm \\
12.52\end{array}$ & $\begin{array}{c}196.0 \pm \\
13.50\end{array}$ & $\begin{array}{c}196.0 \pm \\
16.47\end{array}$ & $\begin{array}{c}206.0 \pm \\
17.13\end{array}$ & $\begin{array}{c}210.0 \pm \\
14.14\end{array}$ \\
\hline $\begin{array}{c}300 \mathrm{mg} / \mathrm{kg} \\
\text { bw } \\
\text { (Treatment I) }\end{array}$ & $200.0 \pm 20.00$ & $\begin{array}{c}204.0 \pm \\
8.94\end{array}$ & $214.0 \pm 8.94$ & $220.0 \pm 7.07$ & $\begin{array}{c}224.0 \pm \\
11.40\end{array}$ & NIL & NIL \\
\hline $\begin{array}{c}1000 \text { mg/ kg } \\
\text { bw } \\
\text { (Treatment II) }\end{array}$ & $192.0 \pm 17.89$ & $\begin{array}{c}186.0 \pm \\
11.40\end{array}$ & $\begin{array}{l}194.0 \pm \\
11.40\end{array}$ & $\begin{array}{l}202.0 \pm \\
16.43\end{array}$ & $\begin{array}{c}212.0 \pm \\
21.68\end{array}$ & NIL & NIL \\
\hline $\begin{array}{c}2000 \text { mg/ kg } \\
\text { bw } \\
\text { (Treatment III) }\end{array}$ & $196.0 \pm 17.76$ & $\begin{array}{c}201.0 \pm \\
15.24\end{array}$ & $\begin{array}{c}203.0 \pm \\
13.37\end{array}$ & $\begin{array}{c}207.0 \pm \\
17.04\end{array}$ & $\begin{array}{c}212.0 \pm \\
18.74\end{array}$ & $\begin{array}{c}210.0 \pm \\
18.26\end{array}$ & $\begin{array}{c}200.0 \pm \\
0.00\end{array}$ \\
\hline
\end{tabular}

Table S6 Absolute and relative organ weight of SD rats following the 28-days repeated dose oral administration of R-38'M water extract and recovery period

\begin{tabular}{lllll}
\hline \multirow{2}{*}{ Organ } & \multicolumn{2}{c}{ Liver } & \multicolumn{2}{c}{ Kidney } \\
\cline { 2 - 5 } Control & Absolute (g) & Relative (\%) & Absolute (g) & Relative (\%) \\
$300 \mathrm{mg} / \mathrm{kg}$ & $7.73 \pm 1.462$ & $3.81 \pm 0.496$ & $1.54 \pm 0.224$ & $0.76 \pm 0.074$ \\
$1000 \mathrm{mg} / \mathrm{kg}$ & $1.54 \pm 0.224$ & $0.76 \pm 0.074$ & $1.76 \pm 0.191$ & $0.78 \pm 0.075$ \\
$2000 \mathrm{mg} / \mathrm{kg}$ & $6.88 \pm 1.200$ & $3.23 \pm 0.290$ & $1.28 \pm 0.115$ & $0.61 \pm 0.039$ \\
Control RP & $7.08 \pm 1.462$ & $3.34 \pm 0.718$ & $1.62 \pm 0.181$ & $0.76 \pm 0.096$ \\
$2000 \mathrm{mg} / \mathrm{kg} \mathrm{RP}$ & $7.22 \pm 0.485$ & $3.44 \pm 0.083$ & $1.57 \pm 0.179$ & $0.75 \pm 0.064$ \\
\hline
\end{tabular}

Values are expressed as mean \pm Standard deviation ( $n=5$; for each group); RP: Recovery period. 